РЫЖОВА Светлана Валентиновна - кандидат социологических наук, ведущий научный сотрудник Института социологии Федерального научно-исследовательского социологического центра Российской академии наук (117218, Россия, г. Москва, ул. Кржижановского, 24/35, корп. 5; Silica2@ yandex.ru)

\title{
РЕЛИГИОЗНОСТЬ И ВОПРОСЫ МЕЖЭТНИЧЕСКИХ ОТНОШЕНИЙ В РОССИИ
}

\begin{abstract}
Аннотация. Роль массовой религиозности россиян не ограничивается функциями ценностной консолидации и обеспечения нравственного единства. Религия стала активным элементом этнической идентичности, усилилась ее роль в межэтнических отношениях. По данным многолетних исследований Центра этнической социологии ФНИСЦ РАН, при ответе на вопрос, что больше всего объединяет их с людьми своей национальности, от 20\% до 60\% опрошенных в разных регионах выбирают религию как признак этнической идентификации и опору этнического самосознания. Актуален вопрос: в условиях массового формирования этноконфессиональных идентичностей и усиления роли религии будет ли религиозность поддерживать межэтническое согласие россиян или, наоборот, укреплять границы и увеличивать дистанцию? В статье автор рассматривает участие религиозного фактора в современных межэтнических отношениях в России с социологической точки зрения.
\end{abstract}

Ключевые слова: религиозность, межэтнические отношения, религиозная идентичность, этноконфессиональная идентичность, православие, ислам

$\Pi$ роблемы религиозности и межэтнических отношений стали актуальными в постсоветской России в связи с усилением межэтнических контактов и актуализацией религиозного сознания, притоком в страну мигрантов-мусульман различных национальностей, принадлежащих к иным религиозно-правовым школам, разногласиями внутри мусульманской уммы России. Немаловажную роль сыграло усиление социальной и политической роли православия как религии этнического большинства и роли ислама как выразителя интересов народов Урало-Поволжья и Северного Кавказа.

Массовая религиозность россиян проявилась в 1990-х гг., в период кризиса государственной идентичности, на этапе острых социально-экономических и политических преобразований. Пробужденное религиозное сознание стало ответом на резкие социальные изменения и девальвацию привычных ценностей. И сегодня, спустя более чем 25 лет, в религии, согласно социологическим опросам, люди находят в первую очередь психологическую опору и нравственные ориентиры. В период 1990-2015 гг. доля тех, кто указывает, что религия помогает им в жизни, выросла с $23 \%$ до 55\% ${ }^{1}$. Верующими и скорее верующими называют себя $85 \%$ россиян ${ }^{2}$, религиозные ценности представлены в политическом и культурном пространстве России.

Как и во всем мире, в России растет политическое влияние религии и становится значимой роль религиозных организаций и лидеров в сохранении межэтнического согласия. Как элемент гражданского общества, религиозные организации в состоянии внести весомый вклад в предупреждение межэтнической и межконфессиональной напряженности. В президиум

\footnotetext{
1 Религия: за и против. Опрос ВЦИОМа в июле 2015 г. Опрошены 1600 чел. в 130 населенных пунктах 46 областей, краев и республик России. Пресс-выпуск № 2888. Доступ: http://wciom.ru/index. php?id=236\&uid=115329 (проверено 15.08.2018).

2 Данные 24-й волны «Российского мониторинга экономического положения и здоровья населения НИУ ВШЭ (RLMS-HSE)», проводимого НИУ ВШЭ и ЗАО «Демоскоп» при участии Центра народонаселения университета Северной Каролины в Чапел Хилле и Института социологии РАН. $R L M S$-HSE. Доступ: http://www.cpc.unc.edu/projects/rlms и http://www.hse.ru/rlms
} 
Межрелигиозного совета РФ входят главы 4 традиционных религий России, а в числе его приоритетных целей указывается противодействие использованию религиозных чувств в разжигании межэтнических конфликтов. В российском массовом сознании соединяются уважение к традиционным религиям и не противоречащее этому стремление к защите светского характера государства. Согласно данным ВЦИОМа, $70 \%$ россиян доверяют РПЦ ${ }^{1}$, но лишь $10 \%$ одобрили бы восстановление государственной религии на законодательном уровне (13\% среди православных и $19 \%$ среди последователей других религий). Большинство российских граждан $(64 \%)^{2}$ поддерживают светский характер государства, закрепленный в Конституции РФ, на государственном уровне признается историческая роль религий России в сохранении традиционных ценностей и нравственного единства.

Между тем роль массовой религиозности россиян не ограничивается только функциями ценностной консолидации. Религия стала активным элементом этнического самосознания (идентичности), усилилась ее роль в межэтнических отношениях. Критерий «религия» при формировании этнической идентичности (в процессах внутриэтнической идентификации и межгрупповой дифференциации) не обладает большой значимостью в мирное время, но у нее велик потенциал этногрупповой мобилизации в периоды межэтнической напряженности. По данным многолетних исследований Центра этнической социологии ФНИСЦ РАН, при ответе на вопрос, что больше всего объединяет их с людьми своей национальности, от $20 \%$ до $60 \%$ опрошенных в разных регионах 3 выбирают религию как признак этнической идентификации и опору этнического самосознания.

Рост массовой религиозности на фоне сохранения этнических культур и стоящих перед государством и обществом задач обеспечения межэтнического согласия и гражданского мира ставит вопрос: не является ли современная российская религиозность тормозом на пути движения страны вперед? В исследованиях Р. Инглхарта и К. Вельцеля утверждается, что модернизация сопровождается развитием ценностей самовыражения и приводит к секуляризации, падению авторитета традиционных религий [Инглхарт, Вельцель 2011]. Однако Хабермас обращает внимание на усиление религиозного фактора внутри современных секулярных государств и призывает учитывать голос религиозно ориентированных граждан, которых государство не должно «отчуждать... от процесса принятия политических решений, даже тогда, когда они приводят религиозные основания» [Хабермас 2011: 125].

Публичные дискуссии о роли традиционных российских религий (прежде всего, православия и ислама), их участии в сохранении ценностей, а также обсуждение проблем религиозного радикализма и мотиваций религиозного террора (в т.ч. вооруженной борьбы за «чистоту веры») побуждают человека к самоопределению в категориях этничности и веры. В этом случае этническая принадлежность и религиозность как неотъемлемый элемент культурной традиции позиционируются в социальных взаимоотношениях и социальных статусах вместе, как недифференцируемая категория, образуя этноконфессиональную

\footnotetext{
1 Динамика оценок одобрения и неодобрения деятельности общественных институтов. ВЦИОМ. 2018. Доступ: https://wciom.ru/news/ratings/odobrenie_deyatelnosti_obshhestvennyx_institutov/ (проверено 18.06.2018).

2 Церковь и общество: вместе или порознь? Инициативный всероссийский опрос ВЦИОМа, проведен 16-17 мая 2015 г. Опрошены 1600 чел. в 130 населенных пунктах 46 областей, краев и республик России. Доступ: https://wciom.ru/index.php?id=236\&uid=61 (проверено 18.06.2018).

3 Опросы в Московской, Астраханской, Калининградской обл., Республике Карелия, г. Москве и Ставропольском крае осуществлены Центром этнической социологии ФНИСЦ РАН (рук. Л.М. Дробижева) в 2014-2017 гг.
} 
идентичность россиян. Введение в школах учебного предмета «Основы религиозных культур и светской этики» способствует формированию и закреплению религиозной и этноконфессиональной идентичности уже на уровне первичной социализации.

Этноконфессиональные процессы, понимаемые как взаимовлияние религии и этничности в социальных отношениях, стали предметом исследования российских ученых сравнительно недавно [Религия в самосознании... 2008], в конце 1990-х гг, когда этничность и религиозность заявили о себе как о серьезных факторах социальной динамики [Авксентьев, Шульга 2014]. Исследователи справедливо отмечают, что этноконфессиональные факторы вступают в силу в том случае, когда существует угроза ущемления прав какойлибо национальности, ущерба ее культурному и традиционному наследию [Кублицкая 2013].

В настоящее время социальный потенциал религиозности в формировании и поддержании межэтнических отношений недостаточно изучен. Актуален вопрос: в условиях массового формирования этноконфессиональных идентичностей и усиления роли религии в поликультурном российском обществе будет ли религиозность поддерживать межэтническое согласие или, наоборот, укреплять границы и увеличивать дистанцию? Радикализация религиозного сознания может выражаться в нетерпимости к представителям иных конфессий или во внутриконфессиональных противоборствах, а также в негативном отношении к представителям определенных национальностей (в силу рутинного соединения этнической и религиозной принадлежности). В силу присутствия религиозной составляющей этноконфессиональная идентичность формируется в сильной кооперации с ценностями и поэтому обладает большим потенциалом социальной регуляции в сфере межэтнических отношений.

Риск вовлечения религии в процессы межэтнической напряженности представляет реальную опасность для социальной стабильности в поликультурных и богатых ресурсами областях и республиках России. Межэтническую напряженность могут провоцировать общественно-политические события, апеллирующие к исторической памяти, восприятие неравных возможностей социального продвижения людей различных национальностей, неравенство в обеспечении ресурсами и перспектив сохранения и развития родной культуры. В случаях ущемления прав той или иной национальности религия может выступать символом внутригрупповой солидарности и питать мотивы восстановления справедливости.

С социологической точки зрения участие религиозного фактора в современных межнациональных (межэтнических) отношениях в России может выражаться в нескольких направлениях: 1) в установках православного большинства по отношению к другим, неправославным конфессиям, прежде всего к исламу и представляющим его этническим сообществам (народы Урало-Поволжья и Кавказа, приезжие из Средней Азии), и в отношении последних к православию и русским; 2) в рисках формирования «низового» религиозного радикализма и фундаментализма (главным образом со стороны православных и мусульман), который может принимать форму взаимной этнической ксенофобии; 3) во влиянии религиозных организаций и духовных лидеров на межэтнические отношения, вовлечении религиозной идентичности в межэтнические конфликты; 4) в межэтнической напряженности, возникающей среди мусульман, принадлежащих к различным религиозно-правовым школам (или отказывающихся от принадлежности); 5) в рисках слияния религии этнического большинства с государством, полиэтническим по своим этнокультурным характеристикам (идеологема современной России как православного государства), и др. 
Согласно декларации ЮНЕСКО ${ }^{1}$, межэтническая толерантность в соответствии с понятием прав человека трактуется как уважение к окружающим, умение сотрудничать с людьми независимо от их этнической и религиозной принадлежности, устойчивость к культурному разнообразию и готовность к мирному урегулированию возникающих конфликтов. В России в условиях этнического и религиозного разнообразия она может быть дополнена принципом «сосуществования различных этноконфессиональных традиций» [Толерантность... 2011: 241].

Доктринальной основой взаимодействия православия и ислама, с которыми себя соотносит большинство населения России, и ресурсом укрепления межнационального согласия являются Основы социальной концепции Русской православной церкви (приняты в 2000 г.) и Основные положения социальной программы российских мусульман (приняты в 2001 г.). Стремление к ненасильственному разрешению межнациональных противоречий, взаимное уважение и диалог, сотрудничество в социальной сфере, любовь к России - эти идеологемы мирного сосуществования двух религиозных традиций широко представлены в данных документах. Согласно социологическим исследованиям, в массовом сознании россиян сложился позитивный образ мусульман. По данным Левада-Центра, $51 \%$ опрошенных положительно воспринимают мусульман (18\% - «очень положительно», 31\% - «в какой-то мере положительно») и еще $31 \%$ - нейтрально («ни положительно, ни отрицательно»). Суммарная доля россиян, воспринимающих мусульман в положительном или нейтральном ключе, составляет $82 \%$. О своем негативном отношении упомянули $14 \%$ (4\% - «очень отрицательно» и $10 \%$ - «в какой-то мере отрицательно») $)^{2}$. Для россиян характерна солидарность с мусульманами в стремлении к защите святынь: $72 \%$ опрошенных согласны с мнением, что «публикации карикатур на пророка Мухаммеда недопустимы, поскольку они оскорбляют мусульман» ${ }^{3}$.

Вместе с тем замеры уровня религиозности и межконфессиональных отношений по общероссийской выборке лишь в некоторой степени позволяют оценить участие религиозного фактора в формировании позитивных или негативных межэтнических отношений. Для реальной оценки роли религиозности в процессах формирования межэтнического согласия или напряженности необходимо исследование этих феноменов на локальном уровне и в региональном разнообразии.

\section{Список литературы}

Авксентьев В.А., Шульга М.М. 2014. Этноконфессиональные отношения в Ставропольском крае: опыт конфликтологического анализа. - Конфликтология. T. 3. C. 148-162.

Инглхарт Р., Вельцель К. 2011. Модернизация, культурные изменения и демократия: Последовательность человеческого развития. М.: Новое издательство. 464 с.

Кублицкая Е.А. 2013. Специфика межэтнического и этноконфессионального взаимодействия в регионах РФ (социологический мониторинг). - Социология религии в обществе позднего модерна (Памяти Е.Ю. Синелиной): материалы III Международной научной конференции. Белгород: ИД «Белгород». С. 249-264.

Религия в самосознании народа (Религиозный фактор в идентификационных процессах) (отв. ред. М.П. Мчедлов). 2008. М.: Институт социологии РАН. 145 с.

Толерантность как фактор противодействия ксенофобии: управление рисками

\footnotetext{
1 Декларация принципов терпимости ЮНЕСКО. 1995. 16 ноября Доступ: http://www.un.org/ru/ documents/decl_conv/declarations/toleranc (проверено 10.05. 2018).

2 https://www.levada.ru/2018/01/23/otnoshenie-k-religiyam/ (проверено 18.06.2018).

3 https://www.levada.ru/2015/01/29/terakt-v-parizhe-karikatury-islam-zaprety/ (проверено 17.06.2018).
} 
ксенофобии в обществе риска (под ред. Ю.П. Зинченко, А.В. Логинова). 2011. М.: Наука. 607 с.

Хабермас Ю. 2011. Между натурализмом и религией. Философские статьи. М.: Весь Мир. 336 с.

RYZHOVA Svetlana Valentinovna, Cand.Sci. (Soc.), Leading Research Fellow, Sociological Institute - branch of the Federal Center of Theoretical and Applied Sociology, Russian Academy of Sciences (bld. 5, 24/35 Krzhizhanovskogo St, Moscow, Russia, 117218; Silica2@yandex.ru)

\title{
RELIGIOSITY AND ISSUES OF INTERETHNIC RELATIONS IN RUSSIA
}

\begin{abstract}
The role of mass religiosity of Russians is not limited to the functions of value consolidation and the provision of moral unity. Religion has become an active element of ethnic consciousness (identity); its role in interethnic relations has increased. The risk of involving religion in the processes of interethnic tension represents a real danger to social stability in multicultural Russia. According to the data of the Center for Ethnic Sociology of the FCTAS RAS, when answering the question about what unites people of one nationality most of all, from $20 \%$ to $60 \%$ of respondents in different regions choose religion as a sign of ethnic identification and the support of ethnic self-awareness. The question is urgent: in the conditions of mass formation of ethno-confessional identities and the strengthening of the role of religion, will religiosity support interethnic accord of Russians or, conversely, strengthen borders and increase distance? For a real assessment of the role of religiosity in the processes of formation of interethnic harmony or tension, it is necessary to study these phenomena at the local level and in regional diversity.
\end{abstract}

Keywords: religiosity, interethnic relations, religious identity, ethno-confessional identity, Orthodoxy, Islam

ГОЛОВИН Евгений Георгиевич - доктор экономических наук, профессор кафедры конституционного и муниципального права Нижегородского института управления - филиала Российской Академии народного хозяйства и государственной служббы при Президенте РФ (603009, Россия, г. Нижний Новгород, пр-кт Гагарина, 46)

\section{ДОПУСКАЕТ ЛИ РАВЕНСТВО РЕЛИГИОЗНЫХ ОБЪЕДИНЕНИЙ ПЕРЕД ЗАКОНОМ СУЩЕСТВОВАНИЕ «ТРАДИЦИОННЫХ РЕЛИГИЙ»?}

Аннотация. В статье рассматриваются проблемы правоприменительной практики реализации кон-
ституционного принципа равенства религиозных объединений перед законом. Автор показывает, что
указанный принцип не означает фактическое равенство прав религиозных объединений, о чем свиде-
тельствует находящаяся в правовом поле практика предоставления государством привилегий конфес-
сиям, относящимся к религиям, “составляющим неотъемлемую часть исторического наследия народов
России». Аргументируется необходимость введения в российское законодательство понятия «традици-
онные религии России».

Ключевые слова: светское государство, равенство религиозных объединений перед законом, фактическое неравноправие религиозных объединений, традиционные религии 